\title{
Understanding Learners' Motivation and Learning Strategies in MOOCs
}

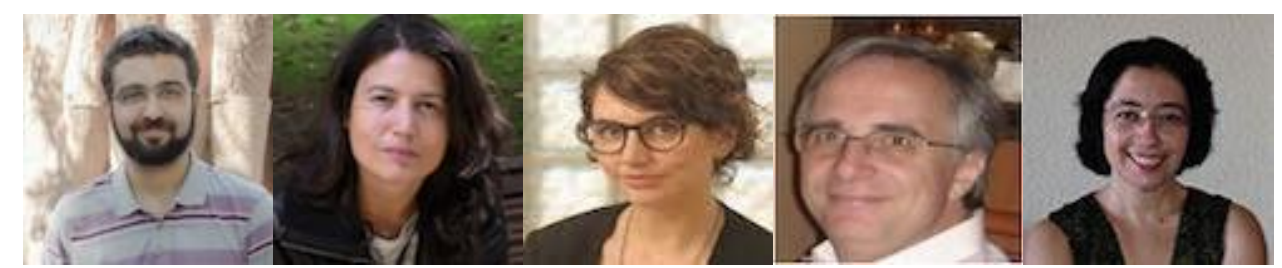

Carlos Alario-Hoyos`, Iria Estévez-Ayres*, Mar Pérez-Sanagustín+, Carlos Delgado Kloos*, and Carmen FernándezPanadero*

*Universidad Carlos III de Madrid, Madrid, Spain; +Pontificia Universidad Católica de Chile, Santiago, Chile

\begin{abstract}
MOOCs (Massive Open Online Courses) have changed the way in which OER (Open Educational Resources) are bundled by teachers and consumed by learners. MOOCs represent an evolution towards the production and offering of structured quality OER. Many institutions that were initially reluctant to providing OER have, however, joined the MOOC wave. Nevertheless, MOOCs detractors strongly criticize their high dropout rates. The dropout rate is a commonly accepted metric of success for traditional education, but it may not be as suitable when dealing with OER, in general, and with MOOCs, in particular, since learners' motivations to take a course are very diverse, and certain selfregulated learning strategies are required to tackle the lack of personalized tutoring and keep pace in the course. This paper presents an empirical study on the motivation and learning strategies of MOOC learners. Six thousand three hundred and thirty-five learners from 160 countries answered a selfreport 7-point Likert-type questionnaire based on the Motivated Strategies for Learning Questionnaire (MSLQ) as part of a MOOC titled Introduction to Programming with Java. Results indicate that learners were highly motivated and confident to do well in the course. Learning strategies, however, can be improved, especially regarding time management.
\end{abstract}

Keywords: MOOCs, OER, motivation, learning strategies, MSLQ

\section{INTRODUCTION}

Open Educational Resources (OER) have been available for decades (Atkins, Brown, \& Hammond, 2007), boosted by the MIT OpenCourseWare (OCW) initiative (Abelson, 2008). Many universities have gradually adhered to OCW, publishing contents from regular courses to be consumed by any learner worldwide, and even using third-party OER to complement and improve teaching on campus. Creating and sharing OER represents an altruistic vision of education, but also has positive effects on 
the visibility of institutions, even providing recruitment advantages in some cases (Carson, Kanchanaraksa, Gooding, Mulder, \& Schuwer, 2012).

OER have traditionally been offered as both textual and audiovisual materials in online repositories, but without any kind of interaction with the teacher who created them, or with other potentially interested learners. MOOCs (Massive Open Online Courses) have managed to evolve the concept of OER, gathering together teachers and learners around courses built on sequences of materials that are typically published using open licenses (Yuan \& Powell, 2013). These communities of teachers and learners created around MOOCs represent a great opportunity for opening debates, curating and enriching course materials, and getting answers from peers without (or with minimum) instructors' intervention (Alario-Hoyos et al., 2013).

MOOCs are succeeding in making universities that were reluctant to join the OER movement rethink their strategy. Providing MOOCs can be seen as an opportunity for promoting the university brand to learners who would have been difficult to reach otherwise, and, at the same time, as a way of improving the quality of residential education by applying MOOC-like technologies and innovations on campus through the so-called SPOCs (Small Private Online Courses) (Fox, 2013). Nonetheless, MOOC detractors criticize their lack of educational value, as most of these courses replicate the traditional lecture-based teaching practices, and the high dropout rates, which in many cases are over 90-95\% of enrollees (Clow, 2013).

The dropout rate is a metric commonly used to measure success in formal education, where learners typically pay a fee to enroll a course and expect to obtain an accreditation certifying that they passed the course. MOOCs, however, remove the entry fee, allowing a much more heterogeneous population of learners with very diverse motivations for enrolling. Their free nature, refreshing knowledge, the opportunity to learn from a top-class university, or simply curiosity, are some of the reasons argued by learners to enroll a MOOC (Davis, Dickens, Leon Urrutia, Sánchez-Vera, \& White, 2014). Finishing and passing the course does not seem a priority anymore for most MOOC enrollees, although that should not stop them from making the most of the MOOC until they believe it is worth their while. The heterogeneous population of learners in MOOCs requires a deep analysis to get information about learners' motivations, with the aim to help to design more attractive courses and promote engagement, which may lead to better retention.

Beyond the role motivation plays in dropout rates, it is noteworthy that learners need some learning strategies, and other advanced self-regulated learning skills, to be able to succeed in MOOCs (Halawa, Greene, \& Mitchell, 2014; Littlejohn \& Milligan, 2016), as there are neither timed face-to-face lectures, nor personalized tutoring with teachers. Learners who report completion of a bachelor's degree or higher are typically more likely to complete MOOCs (Ho et al., 2014); this can be explained by the development of self-regulated learning skills during undergraduate studies and beyond. The heterogeneous background and skills of learners also requires a deep analysis to get information about learners' self-regulated learning strategies, with the aim to complement MOOCs with activities that allow for a more personalized monitoring of learners, helping them to better organize their time and providing hints for scaffolding self-regulated learning (Gutiérrez-Rojas, Alario-Hoyos, PérezSanagustín, Leony, \& Delgado Kloos, 2014).

The objective of this paper is to provide insights into the motivation and learning strategies that characterize MOOC learners. These insights come from an empirical study conducted in a MOOC 
titled Introduction to Programming with Java, deployed in the edX platform. This MOOC is selected because it had a big impact, attracted a wide range of learners' nationalities and backgrounds, and was delivered in both synchronous and self-paced modes. The empirical study is supported by the Motivated Strategies for Learning Questionnaire (MSLQ) (Pintrich, Smith, García, \& McKeachie, 1991; Pintrich, Smith, García, \& McKeachie, 1993), which is a widely used self-report Likert-type questionnaire for analyzing motivation and learning strategies in educational settings (Colorado \& Eberle, 2010; Morales Chan, Hernández Rizzardini, Barchino Plata, \& Amelio Medina, 2015).

The remainder of this paper continues analyzing the related work. Then, the MOOC employed in the study is briefly presented, summarizing the demographics of the learners that participated in the study, and the data collection and analysis methods. Results from learners' answers are detailed and discussed afterwards. Finally, the paper finishes drawing the conclusions of the empirical study and indicating some of the future lines of work.

\section{Related Work}

Since the advent of MOOCs, it became clear that these courses exhibit a set of characteristics, mainly its openness and the possibility to reach potentially thousands of learners, which set them apart from more traditional courses. Although some media initially presented MOOCs as the panacea for the problems of Higher Education (Pappano, 2012), soon researchers and academia tempered this early excitement, understanding, at the same time, that traditional learning indicators, such as completion rates, had to be complemented with other metrics to measure the success and impact of MOOCs (Riel \& Lawless, 2017).

According to systematic literature reviews (Liyanagunawardena, Adams, \& Williams, 2013; Veletsianos \& Shepherdson, 2016), many empirical studies related to MOOCs have tackled the task of characterizing these courses by studying participation patterns, participants' demographics and intentions, types of design, and use of learning analytics. The work by Gasevic, Kovanovic, Joksimovic, and Siemens (2014) analyzed 266 project proposals submitted to the MOOC Research Initiative (MRI) funded by the Gates Foundation, identifying motivation and self-regulated learning (Zimmerman, 2002) as two of the five main research themes for future research in MOOCs. Actually, different studies (DeBoer et al., 2013; Gasevic, Kovanovic, Joksimovic, and Siemens, 2014; Riel \& Lawless, 2017; Terras \& Ramsey, 2015; De Barba, Kennedy, \& Ainley, 2016) agree on the necessity of more analysis of learners' motivation, self-regulated learning strategies, attitudes, and behavior, in order to gain insight and enable a more efficient learning and teaching MOOC experience. This section goes through the literature on motivation and self-regulated learning strategies in MOOCs and the instruments to measure them, from which we derive the main research questions of this work.

\section{Motivation in MOOCs}

Motivation plays a significant role in learners' self-regulated learning (Pintrich, 1999; Schunk \& Zimmerman, 1998). Prior works on self-regulated learning make a distinction between intrinsic and extrinsic motivation. While extrinsic motivation is related with external values and demands (Deci, Vallerand, Pelletier, \& Ryan, 1991), intrinsic motivation refers to doing an activity for the enjoyment and inherent satisfaction of performing a task (Ryan \& Deci, 2000), this latter having more weight in 
the learning achievements and attitudes of traditional learners (Gottfried, Marcoulides, Gottfried, Oliver, \& Guerin, 2007).

Both intrinsic motivation, in the form of perceived enjoyment, and extrinsic motivation, as perceived usefulness or task value, have been found to play a role on learners' attitudes towards online courses (Lee, Cheung, \& Chen, 2005). In MOOCs, where the population of learners is heterogeneous and people register with different intentions, motivation plays a key role on how learners will address the course (Kizilcec \& Halawa, 2015; Hood, Littlejohn, \& Milligan, 2015). However, in MOOCs, unlike in other types of online courses, learners' intrinsic motivation for the subject addressed is of higher importance, as the certification obtained after completion (extrinsic motivation) has typically a low recognition (Wang \& Baker, 2015). Gamification and collaborative learning are some of the main strategies that are being explored in the literature to increase learners' intrinsic motivation in MOOCs (Gené, Núñez, \& Blanco, 2014; Vaibhav \& Gupta, 2014; Collazos, González, \& García, 2014).

\section{Self-Regulated Learning Strategies in MOOCs}

Self-regulated learning is the ability of the learner to control and regulate his own learning through the usage of cognitive and metacognitive strategies (Zimmerman 2002). According to various researchers, self-regulation is something that is not fixed, but influenced as people learn, so it can be trained through learning strategies (Schunk, 2005). Based on this notion, Pintrich, Smith, García, \& McKeachie (1993) identified three categories of strategies that students should employ to regulate their own learning: (1) cognitive strategies, which refer to activities that learners utilize in the acquisition, storage, and retrieval of information; (2) metacognitive strategies, which refer to activities utilized by learners for monitoring and reflecting on their learning process to accomplish a goal; and (3) resource management strategies, which refer to activities students use to manage their time, study environments, and the resources provided.

It is already established that effective learning depends on the nature and sequencing of self-regulated activities by the learner (Bannert \& Reimann, 2012); and although self-regulation skills and learning strategies are needed for any educational context, they are more important in a technology-enhanced learning environment (Lin, Hmelo, Kinzer, \& Secules, 1999). In MOOCs, where there is no guidance or support from an instructor, and the course is not structured around classes, learners' ability to selfregulate their own learning process is especially relevant (Hood et al., 2015; Cohen \& Magen-Nagar, 2016).

Researchers studying self-regulation in MOOCs have pointed out that self-regulated learning strategies, such as metacognitive strategies and time management, are among the most critical ones for learners. Time management is a specific, self-regulated learning skill that includes scheduling, planning, and managing the personal study time. Studies reveal that poor time management is one of the main reasons for withdrawing from MOOC, along with the lack of attractiveness and suitability of the course for each learner (Nawrot \& Doucet 2014; Kizilcec \& Halawa, 2015; Zheng, Rosson, Shih, \& Carroll, 2015). Furthermore, in a recent article by Kizilcec, Pérez-Sanagustín, and Maldonado (2016) in which the authors interviewed 17 learners who successfully completed a MOOC, time management strategies, such as reserving time in the week for studying, were identified as some of the most effective self-regulation learning strategies. 


\section{Measuring Motivation and Self-regulated Learning Strategies}

One of the most well-known instruments to assess both learners' motivation and self-regulated learning strategies is the Motivated Strategies for Learning Questionnaire (MSLQ), which was proposed by Pintrich et al. (1993). The MSLQ is a self-report instrument designed to measure learners' motivation and self-regulated learning in classroom contexts. Although this instrument has been mainly applied in traditional learning settings, some studies have used it to understand the motivation and learning strategies of MOOC learners. For example, Magen-Nagar \& Cohen (2016) conducted an experiment in Israel with 164 high school students taking two different MOOCs. Their study concludes that learners with higher motivation use better learning strategies, and this leads to a higher sense of achievement. Morales Chan et al. (2015), used the MSQL to study the motivational and cognitive learning strategies of learners from a MOOC on Cloud-based Tools for Learning developed by Galileo University in Guatemala. However, their sample only included 230 students with most of them from the same country (Guatemala).

Recently, some researchers proposed adaptations of the MSLQ to be applied in MOOCs. One example is the instrument designed by Hood, Littlejohn, \& Milligan (2015). This instrument was a slightly modified version of an instrument by Fontana, Milligan, Littlejohn, and Margaryan (2015) for assessing self-regulated learning in adult learners in the workplace, which integrated items from the MSLQ together with other learning strategies. They ran the instrument with 788 learners from 79 countries enrolled in an introductory data science course. The study concludes that the learner's context and role have a positive impact in their attitude towards a MOOC and that those learners with prior knowledge in the field obtained better scores. Based on the instrument by Hood et al. (2015), and Barnard, Paton, and Lan (2008), Kizilcec, Pérez-Sanagustín, and Maldonado (2017) proposed another questionnaire to measure self-regulated learning skills in MOOC learners. The questionnaire was used with 4831 learners in six different MOOCs. Results showed that goal setting and strategic planning are better predictors for attainment of personal course goals. Finally, a recent study by Jansen, Van Leeuwen, Janssen, Kester, and Kalz (2016) proposed another questionnaire for measuring self-regulated learning in MOOCs. In this case, they took as a reference a combination of questionnaires defined in the literature of self-regulated learning and adapted them to the MOOC content. In this work, they extended the MSLQ to include more questions related with the preparatory and appraisal phases of the self-regulated learning process, according to other theoretical models in the literature (Puustinen \& Pulkkinen, 2001); however, this latter questionnaire suppressed some of the questions related with the model by Pintrich, Smith, García, \& McKeachie (1991) and Pintrich et al. (1993), which is the model that will be taken as a basis for this work.

\section{Research Questions}

The current literature demands a deeper investigation on the characterization of MOOC learners regarding motivation and self-regulated learning strategies. Thus, we pose the following two research questions:

- RQ1: What are the motivations that characterize MOOC learners?

- RQ2: What are the self-regulated learning strategies that characterize MOOC learners?

Concerning RQ1, most works in the literature have studied learners' intentions when enrolling MOOCs (Kizilcec \& Halawa, 2015; Hood et al., 2015), detecting that learners' intentions had a strong relationship with their motivation. However, there are very few large-scale studies of the motivation 
that characterizes MOOC learners, and of the studies that can be found in the literature, there is a focus on learners from specific regions or homogeneous sociocultural characteristics (Magen-Nagar \& Cohen, 2016; Morales Chan et al., 2015; Kizilcec, Pérez-Sanagustín, and Maldonado, 2017).

Concerning RQ2, the information on current studies about self-regulated learning strategies, which are more effective for learners to succeed in MOOCs, is scarce. On the one hand, existing studies focus on different aspects of self-regulation, providing only a small picture of what self-regulated learning strategies MOOC learners use (Nawrot \& Doucet 2014; Kizilcec, Pérez-Sanagustín, and Maldonado, 2016). On the other hand, most existing studies collect information only from MOOCs that attract a quite homogeneous set of learners from a sociocultural perspective (Magen-Nagar \& Cohen, 2016; Morales Chan et al., 2015; Kizilcec et al., 2017).

All in all, there is need for more empirical studies on learners' motivation and self-regulated learning strategies in MOOCs with the aim to extend the data spectrum and contribute to the design and development of more engaging and effective courses.

\section{Materials and Methods}

\section{Background of the Course}

The empirical research presented here is supported by data obtained from a MOOC titled Introduction to Programming with Java, which was deployed in the edX platform. This MOOC included video-based lectures and numerous interactive activities (Alario-Hoyos et al., 2016); all the materials generated for this course were offered as OER under a Creative Common license (CC-BYNC-SA). This MOOC ran twice during two consecutive editions (runs) of the MOOC in the years 2015 and 2016. The first run followed a synchronous approach, and materials were released weekly; the second run followed a self-paced approach, and all the materials were available from the beginning. Table 1 presents an overview of the general information of the MOOC. This general information was available for learners before enrolling the MOOC. In total, 228,979 learners enrolled in the two runs of the MOOC.

Table 1

General Information on MOOC Titled Introduction to Programming with Java

\begin{tabular}{|c|c|}
\hline Title & $\begin{array}{l}\text { IT.1.1x Introduction to Programming with Java - Part 1: Starting to Program } \\
\text { in Java ( } 1^{\text {st }} \text { run) } \\
\text { IT.1.1x Introduction to Programming with Java - Part 1: Starting to Code } \\
\text { with Java ( } 2^{\text {nd }} \text { run) }\end{array}$ \\
\hline Platform & edX \\
\hline Dates & $\begin{array}{l}\text { April, 28, 2015 - June 30, } 2015\left(1^{\text {st }} \text { run }- \text { synchronous }\right) \\
\text { November } 17,2015 \text { - June } 30,2016\left(2^{\text {nd }} \text { run }- \text { self-paced }\right)\end{array}$ \\
\hline Length & 5 weeks \\
\hline $\begin{array}{l}\text { Estimated } \\
\text { workload }\end{array}$ & $\begin{array}{l}\text { 5-7 hours per week ( } 1^{\text {st }} \text { run) } \\
\text { 7-10 hours per week ( } 2^{\text {nd }} \text { run, adjusted based on learners' feedback) }\end{array}$ \\
\hline Area & Computer science \\
\hline Institution & Universidad Carlos III de Madrid (UC3M), Spain \\
\hline Level & Introductory \\
\hline Language & English \\
\hline
\end{tabular}




\begin{tabular}{|l|l|}
\hline $\begin{array}{l}\text { Video } \\
\text { Transcripts }\end{array}$ & English, Spanish, Portuguese, Mandarin \\
\hline Prerequisites & None \\
\hline $\begin{array}{l}\text { Number of } \\
\text { teachers }\end{array}$ & 8 \\
\hline Assessment type & $\begin{array}{l}\text { Quizzes and peer review (1st edition) } \\
\text { Quizzes (2 } 2^{\text {nd }} \text { edition) }\end{array}$ \\
\hline
\end{tabular}

\section{Data Collection Methods}

Data for the analysis of learners' motivations and learning strategies was collected using a self-report, voluntary, and anonymous questionnaire filled in by learners of this MOOC during the two consecutive runs in 2015 and 2016. Learners could complete the questionnaire at any time, as long as the course in which they were enrolled was active.

The questionnaire was a 7-point Likert scale questionnaire from 1 (lowest) to 7 (highest), based on MSLQ (Pintrich et al., 1991; Pintrich et al., 1993) with two parts: a first part with a set of assertions to be assessed in relation with learners' motivation to participate in the MOOC, and their preferences on materials and assignments; and a second part with a set of assertions to be assessed in relation with learners' self-regulation learning strategies. The questionnaire was designed containing a subset of categories from MSLQ, with a total of 30 assertions to be assessed (see Table 3). There were several categories could not be directly applied to MOOCs, in general, and of this MOOC in particular, and so these categories were not included in the questionnaire. Reasons for not including categories from MSLQ were: the category refers to physical situations that typically take place in a classroom, and the assertions cannot be easily adapted to online learning (e.g., category named Help Seeking); the category assumes that taking this course is mandatory, while enrolling in a MOOC is a voluntary choice (e.g., category named Effort Regulation); the category assumes that the learner takes a final exam, while this MOOC follows a continuous evaluation system (e.g., category named Test Anxiety); the category relies on memorization as the base of learning, while this MOOC relies on practicing and interaction (e.g., category named Rehearsal). Once the categories were selected, some of their assertions required minor adjustments to make sense in the particular educational setting of a MOOC context. The complete list of assertions is presented in the next section. Overall, 18 questions out of the 31 on motivation, and 12 questions out of the 50 on learning strategies were included in the questionnaire.

Table 2

Categories of MSLQ Included in the Questionnaire

\begin{tabular}{|l|l|}
\hline \multirow{5}{*}{ Motivation } & Value Component: Intrinsic Goal Orientation (IGO) (4 assertions) \\
\cline { 2 - 3 } & Value Component: Task Value (TV) (6 assertions) \\
\cline { 2 - 3 } & $\begin{array}{l}\text { Expectancy Component: Self-Efficacy for Learning and Performance } \\
\text { (SELP) (8 assertions) }\end{array}$ \\
\hline $\begin{array}{l}\text { Learning } \\
\text { Strategies }\end{array}$ & $\begin{array}{l}\text { Cognitive and metacognitive strategies: Critical Thinking (CT) (5 } \\
\text { assertions) }\end{array}$ \\
\cline { 2 - 2 } $\begin{array}{l}\text { Resource management strategies: Time and Study Environment (TSE) (7 } \\
\text { assertions) }\end{array}$ \\
\hline
\end{tabular}




\section{Sample Size and Demographics}

Of the 228,979 learners who enrolled in this MOOC, 6335 (2.8\%) volunteered to complete the questionnaire about motivation and learning strategies. Table 3 shows the (self-reported) demographics for the participants in the study. It is interesting to note that 160 countries are represented in the sample and that there is certain heterogeneity in the age, level of education, and previous background in the field of the learners that participated in the study.

Table 3

Sample Size and Self-Reported Demographics of Participants in the Study

\begin{tabular}{|c|c|}
\hline $\begin{array}{l}\text { Total number of } \\
\text { enrollees }\end{array}$ & 228,979: 93,556 ( $1^{\text {st }}$ run $), 135,423$ ( $2^{\text {nd }}$ run $)$ \\
\hline Sample size & 6335 (2.8\% of enrollees) \\
\hline Gender & $\begin{array}{l}\text { - Male: } 4915(77.6 \%) \\
\text { - Female: } 1399(22.1 \%) \\
\text { - Other: } 21(0.3 \%)\end{array}$ \\
\hline Age & $\begin{array}{l}\text { - < } 18: 423(6.68 \%) \\
\text { - } 18-24: 2142(33.81 \%) \\
\text { - } 25-29: 1229(19.40 \%) \\
\text { - } 30 \text { - 34: } 835(13.18 \%) \\
\text { - } 35-39: 557(8.79 \%) \\
\text { - } 40-44: 364(5.75 \%) \\
\text { - } 45 \text { - 49: } 270(4.26 \%) \\
\text { - > } 50: 515(8.13 \%)\end{array}$ \\
\hline $\begin{array}{l}\text { Highest level of } \\
\text { education achieved }\end{array}$ & $\begin{array}{l}\text { - Doctorate: } 131 \text { (2.07\%) } \\
\text { - Master's or Professional Degree: } 1376 \text { (21.72\%) } \\
\text { - Bachelor's Degree: } 2353(37.14 \%) \\
\text { - Associate's Degree: } 390 \text { (6.16\%) } \\
\text { - Secondary/High School: } 1676(26.46 \%) \\
\text { - Junior secondary / junior high / middle school: } 255 \text { (4.03\%) } \\
\text { - Elementary / primary school: } 36 \text { (o.57\%) } \\
\text { - None: } 13(0.21 \%) \\
\text { - Other: } 105(1.66 \%)\end{array}$ \\
\hline $\begin{array}{l}\text { Number of countries } \\
\text { represented }\end{array}$ & $\begin{array}{l}\text { 160 countries } \\
\text { - Asia: } 1856 \text { learners (29.3\%), } 43 \text { countries. } \\
\checkmark \text { Top three: India (1199), Philippines (92), Pakistan (81) } \\
\text { - Europe: } 1593 \text { learners (25.15\%), } 44 \text { countries. } \\
\checkmark \text { Top three: Spain (302), United Kingdom (140), Ukraine (121) } \\
\text { - North America: } 1517 \text { learners (23.95\%), 3 countries. } \\
\checkmark \quad \text { Top three: USA (1075), Mexico (303), Canada (139) } \\
\text { - South America: } 696 \text { learners (10.99\%), 12 countries. } \\
\checkmark \quad \text { Top three: Brazil (244), Colombia (142), Venezuela (80) } \\
\text { - Africa: } 428 \text { learners (6.76\%), 37 countries. } \\
\checkmark \quad \text { Top three: Nigeria (109), Egypt (69), South Africa (51) } \\
\text { - Central America and the Caribbean: 170 learners (2.68\%), } 17 \\
\text { countries. } \\
\checkmark \quad \text { Top three: Dominican Republic (38), Costa Rica (26), } \\
\text { Guatemala (25) } \\
\text { - Oceania: 75 learners (1.28\%), } 4 \text { countries. } \\
\checkmark \quad \text { Top three: Australia (59), New Zealand (12), Fiji (3) }\end{array}$ \\
\hline $\begin{array}{l}\text { Working in a job or } \\
\text { business }\end{array}$ & $\begin{array}{l}\text { - Yes: } 3376(53.29 \%) \\
\text { - No: } 2956(46.71 \%)\end{array}$ \\
\hline Teaching experience & $\begin{array}{l}\text { - Yes: } 1487(23.47 \%) \text { [in computer science } 654(10.32 \%)] \\
\text { - No: } 4848(76.53 \%)\end{array}$ \\
\hline
\end{tabular}




\begin{tabular}{|l|l|}
\hline $\begin{array}{l}\text { Previous computing } \\
\text { or statistical } \\
\text { experience }\end{array}$ & $\begin{array}{l}\text { ・ Yes: } 4408(69.58 \%) \\
\text { • No: } 1927(30.42 \%)\end{array}$ \\
\hline
\end{tabular}

\section{Data Analysis Methods}

The data collected from the questionnaire have a quantitative nature taking discrete integer values with 1 as the minimum value and 7 as the maximum value. Descriptive statistics are used to analyze these data in order to better understand motivation and learning strategies through this sample of MOOC learners. More specifically, the central tendency of these data is evaluated through the mean value (M), and the variability through the standard deviation (Std.).

\section{Results}

The results are divided into two blocks: motivation and learning strategies. In total, 6335 learners volunteered to complete the questionnaire, which had two phases. In the first phase learners had to assess assertions related to motivation. In the second phase learners had to assess assertions related to learning strategies.

\section{Motivation}

Learners assessed 18 MSLQ assertions about their motivation to participate in the MOOC and their preferences on materials and assignments (Table 4). These assertions are grouped in three categories: IGO (Intrinsic Goal Orientation), TV (Task Value), and SELP (Self-Efficacy for Learning and Performance). Each assertion received exactly 6335 answers.

The four assertions on IGO obtained high rates from learners, who pointed out their preference for challenging materials $(\mathrm{M}=5.65, \mathrm{Std} .=1.33)$ that trigger curiosity $(\mathrm{M}=5.84$, Std. $=1.25)$. Interestingly, learners also reported their wish to delve into the contents $(\mathrm{M}=6.04$, Std. $=1.16)$, and to complete all the course assignments even if that did not mean getting good grades $(\mathrm{M}=5.92, \mathrm{Std}$. $=$ 1.24).

The six assertions on TV obtained very high rates from learners, showing that this particular course arouse great interest among them. Both the subject of this MOOC (programming with Java) and the area of knowledge (computer science) represent a great source of motivation for learners $(\mathrm{M}=6.08$, Std. $=1.13$, and $M=6.07$, Std. = 1.13, respectively). The potential usefulness of the materials to be studied is also well assessed $(\mathrm{M}=6.18$, Std. $=1.09)$, considering learners of importance the proper learning $(M=5.94$, Std. $=1.27)$ and understanding $(M=6.09$, Std. $=1.17)$ of these materials, as well as their potential application in the future $(M=5.94$; Std. $=1.23)$.

The eight assertions on SELP also obtained high rates from learners, which generally rely on their ability to learn, not only basic concepts $(M=6.22$, Std. $=1.11)$, but also the most complex $(M=5.45$, Std. $=1.40)$ and difficult materials $(M=5.28$, Std. $=1.45)$ of the MOOC. Learners' self-esteem leads them to believe that they will do well in the course $(M=5.77$, Std. $=1.23)$, master the skills that will be taught $(\mathrm{M}=5 \cdot 77$, Std. = 1.28), do an excellent job in exams and assignments $(\mathrm{M}=5.58$, Std. = 1.31), and get an excellent grade at the end of the $\operatorname{MOOC}(M=5.47$, Std. $=1.37)$. 
Table 3

Learners' Self-Reported Answers to Assertions on Motivation

\begin{tabular}{|c|c|c|c|c|c|c|c|c|c|c|}
\hline Type & Assertion & $\mathbf{1}$ & 2 & 3 & 4 & 5 & 6 & 7 & $\begin{array}{c}\text { Mea } \\
n\end{array}$ & Std. \\
\hline \multirow{4}{*}{ IGO } & $\begin{array}{l}\text { In a course like this, I prefer course } \\
\text { material that really challenges me } \\
\text { so I can learn new things. }\end{array}$ & $\begin{array}{c}92 \\
(1.5 \%)\end{array}$ & $\begin{array}{c}98 \\
(1.5 \%)\end{array}$ & $\begin{array}{c}212 \\
(3.3 \%)\end{array}$ & $\begin{array}{c}705 \\
(11.1 \%)\end{array}$ & $\begin{array}{c}1369 \\
(21.6 \%)\end{array}$ & $\begin{array}{c}1785 \\
(28.2 \% \\
\end{array}$ & $\begin{array}{c}2074 \\
(32.7 \%)\end{array}$ & 5.65 & 1.33 \\
\hline & $\begin{array}{l}\text { In a course like this, I prefer course } \\
\text { material that arouses my curiosity, } \\
\text { even if it is difficult to learn. }\end{array}$ & $\begin{array}{c}52 \\
(0.8 \%)\end{array}$ & $\begin{array}{c}82 \\
(1.3 \%)\end{array}$ & $\begin{array}{c}165 \\
(2.6 \%)\end{array}$ & $\begin{array}{c}576 \\
(9.1 \%)\end{array}$ & $\begin{array}{c}1208 \\
(19.1 \%)\end{array}$ & $\begin{array}{c}1844 \\
(29.1 \%)\end{array}$ & $\begin{array}{c}2408 \\
(38 \%)\end{array}$ & 5.84 & 1.25 \\
\hline & $\begin{array}{l}\text { The most satisfying thing for me in } \\
\text { this course will be trying to } \\
\text { understand the content as } \\
\text { thoroughly as possible. }\end{array}$ & $\begin{array}{c}48 \\
(0.8 \%)\end{array}$ & $\begin{array}{c}49 \\
(0.8 \%)\end{array}$ & $\begin{array}{c}117 \\
(1.8 \%)\end{array}$ & $\begin{array}{c}410 \\
(6.5 \%)\end{array}$ & $\begin{array}{c}969 \\
(15 \cdot 3 \%)\end{array}$ & $\begin{array}{c}1902 \\
(30 \%)\end{array}$ & $\begin{array}{c}2840 \\
(44.8 \% \\
)\end{array}$ & 6.04 & 1.16 \\
\hline & $\begin{array}{l}\text { When I have the opportunity in this } \\
\text { kind of courses, I try to do all the } \\
\text { exercises and course assignments } \\
\text { that I can learn from even if they } \\
\text { don't guarantee a good grade. }\end{array}$ & $\begin{array}{c}60 \\
(0.9 \%)\end{array}$ & $\begin{array}{c}88 \\
(1.4 \%)\end{array}$ & $\begin{array}{c}126 \\
(2 \%)\end{array}$ & $\begin{array}{c}516 \\
(8.1 \%)\end{array}$ & $\begin{array}{c}1037 \\
(16.4 \%)\end{array}$ & $\begin{array}{c}1936 \\
(30.6 \% \\
)\end{array}$ & $\begin{array}{c}2572 \\
(40.6 \% \\
)\end{array}$ & 5.92 & 1.24 \\
\hline \multirow{6}{*}{ TV } & $\begin{array}{l}\text { I think I will be able to use what I } \\
\text { will learn in this course in other } \\
\text { courses. }\end{array}$ & $\begin{array}{c}67 \\
(1.1 \%)\end{array}$ & $\begin{array}{c}61 \\
(1 \%)\end{array}$ & $\begin{array}{c}148 \\
(2.3 \%)\end{array}$ & $\begin{array}{c}472 \\
(7.5 \%)\end{array}$ & $\begin{array}{c}1030 \\
(16.3 \%)\end{array}$ & $\begin{array}{c}1922 \\
(30.3 \% \\
\end{array}$ & $\begin{array}{c}2635 \\
(41.6 \%)\end{array}$ & 5.94 & 1.23 \\
\hline & $\begin{array}{l}\text { It is important for me to learn the } \\
\text { material in this course. }\end{array}$ & $\begin{array}{c}69 \\
(1.1 \%)\end{array}$ & $\begin{array}{c}76 \\
(1.2 \%) \\
\end{array}$ & $\begin{array}{c}164 \\
(2.6 \%) \\
\end{array}$ & $\begin{array}{c}526 \\
(8.3 \%) \\
\end{array}$ & $\begin{array}{c}980 \\
(15.5 \%)\end{array}$ & $\begin{array}{c}1739 \\
(27.5 \%) \\
\end{array}$ & $\begin{array}{c}2781 \\
(43.9 \%) \\
\end{array}$ & 5.94 & 1.27 \\
\hline & $\begin{array}{l}\text { I am very interested in the content } \\
\text { area of this course. }\end{array}$ & $\begin{array}{c}53 \\
(0.8 \%)\end{array}$ & $\begin{array}{c}20 \\
(0.3 \%)\end{array}$ & $\begin{array}{c}100 \\
(1.6 \%)\end{array}$ & $\begin{array}{c}420 \\
(6.6 \%)\end{array}$ & $\begin{array}{c}958 \\
(15.1 \%)\end{array}$ & $\begin{array}{c}1895 \\
(29.9 \%)\end{array}$ & $\begin{array}{c}2889 \\
(45.6 \%)\end{array}$ & 6.07 & 1.13 \\
\hline & $\begin{array}{l}\text { I think the course material in this } \\
\text { course will be useful for me to } \\
\text { learn. }\end{array}$ & $\begin{array}{c}49 \\
(0.8 \%)\end{array}$ & $\begin{array}{c}39 \\
(0.6 \%)\end{array}$ & $\begin{array}{c}74 \\
(1.2 \%)\end{array}$ & $\begin{array}{c}320 \\
(5.1 \%)\end{array}$ & $\begin{array}{c}784 \\
(12.4 \%)\end{array}$ & $\begin{array}{c}1899 \\
(30 \%)\end{array}$ & $\begin{array}{c}3170 \\
(50 \%)\end{array}$ & 6.18 & 1.09 \\
\hline & $\begin{array}{l}\text { I like the subject matter of this } \\
\text { course. }\end{array}$ & $\begin{array}{c}49 \\
(0.8 \%)\end{array}$ & $\begin{array}{c}40 \\
(0.6 \%)\end{array}$ & $\begin{array}{c}73 \\
(1.2 \%)\end{array}$ & $\begin{array}{l}445 \\
(7 \%)\end{array}$ & $\begin{array}{c}881 \\
(13 \cdot 9 \%)\end{array}$ & $\begin{array}{c}1953 \\
(30.8 \% \\
)\end{array}$ & $\begin{array}{c}2894 \\
(45 \cdot 7 \%)\end{array}$ & 6.08 & 1.13 \\
\hline & $\begin{array}{l}\text { Understanding the subject matter } \\
\text { of this course is very important to } \\
\text { me. }\end{array}$ & $\begin{array}{c}57 \\
(0.9 \%)\end{array}$ & $\begin{array}{c}53 \\
(0.8 \%)\end{array}$ & $\begin{array}{c}107 \\
(1.7 \%)\end{array}$ & $\begin{array}{c}405 \\
(6.4 \%)\end{array}$ & $\begin{array}{c}842 \\
(13 \cdot 3 \%)\end{array}$ & $\begin{array}{c}1815 \\
(28.7 \%)\end{array}$ & $\begin{array}{c}3056 \\
(48.2 \% \\
) \\
\end{array}$ & 6.09 & 1.17 \\
\hline \multirow{8}{*}{ SELP } & $\begin{array}{l}\text { I believe I will receive an excellent } \\
\text { grade in this course. }\end{array}$ & $\begin{array}{c}94 \\
(1.5 \%)\end{array}$ & $\begin{array}{c}123 \\
(1.9 \%)\end{array}$ & $\begin{array}{c}300 \\
(4 \cdot 7 \%)\end{array}$ & $\begin{array}{c}916 \\
(14 \cdot 5 \%)\end{array}$ & $\begin{array}{c}1382 \\
(21.8 \%)\end{array}$ & $\begin{array}{c}1820 \\
(28.7 \%)\end{array}$ & $\begin{array}{c}1700 \\
(26.8 \% \\
)\end{array}$ & $5 \cdot 47$ & 1.37 \\
\hline & $\begin{array}{l}\text { I am certain I can understand the } \\
\text { most difficult material presented in } \\
\text { this course. }\end{array}$ & $\begin{array}{c}112 \\
(1.8 \%)\end{array}$ & $\begin{array}{c}206 \\
(3 \cdot 3 \%)\end{array}$ & $\begin{array}{c}421 \\
(6.6 \%)\end{array}$ & $\begin{array}{c}947 \\
(14.9 \%)\end{array}$ & $\begin{array}{c}1496 \\
(23.6 \%)\end{array}$ & $\begin{array}{c}1680 \\
(26.5 \%)\end{array}$ & $\begin{array}{c}1473 \\
(23 \cdot 3 \%)\end{array}$ & 5.28 & 1.45 \\
\hline & $\begin{array}{l}\text { I am confident I can learn the basic } \\
\text { concepts taught in this course. }\end{array}$ & $\begin{array}{c}53 \\
(0.8 \%) \\
\end{array}$ & $\begin{array}{c}36 \\
(0.6 \%) \\
\end{array}$ & $\begin{array}{c}87 \\
(1.4 \%) \\
\end{array}$ & $\begin{array}{c}343 \\
(5.4 \%) \\
\end{array}$ & $\begin{array}{c}673 \\
(10.6 \%) \\
\end{array}$ & $\begin{array}{c}1694 \\
(26.7 \%) \\
\end{array}$ & $\begin{array}{c}3449 \\
(54.4 \%) \\
\end{array}$ & 6.22 & 1.11 \\
\hline & $\begin{array}{l}\text { I am confident I can understand } \\
\text { the most complex materials that } \\
\text { will be presented by the instructor } \\
\text { in this course. }\end{array}$ & $\begin{array}{c}91 \\
(1.4 \%)\end{array}$ & $\begin{array}{c}167 \\
(2.6 \%)\end{array}$ & $\begin{array}{c}346 \\
(5 \cdot 5 \%)\end{array}$ & $\begin{array}{c}785 \\
(12.4 \%)\end{array}$ & $\begin{array}{c}1410 \\
(22.3 \%)\end{array}$ & $\begin{array}{c}1853 \\
(29.3 \%)\end{array}$ & $\begin{array}{c}1683 \\
(26.6 \%)\end{array}$ & $5 \cdot 45$ & 1.40 \\
\hline & $\begin{array}{l}\text { I am confident I can do an excellent } \\
\text { job on the assignments and tests in } \\
\text { this course. }\end{array}$ & $\begin{array}{c}63 \\
(1 \%)\end{array}$ & $\begin{array}{c}115 \\
(1.8 \%)\end{array}$ & $\begin{array}{c}233 \\
(3.7 \%)\end{array}$ & $\begin{array}{c}808 \\
(12.8 \%)\end{array}$ & $\begin{array}{c}1390 \\
(21.9 \%)\end{array}$ & $\begin{array}{c}1932 \\
(30.5 \%)\end{array}$ & $\begin{array}{c}1794 \\
(28.3 \% \\
\end{array}$ & 5.58 & 1.31 \\
\hline & I expect to do well in this class. & $\begin{array}{c}60 \\
(0.9 \%)\end{array}$ & $\begin{array}{c}79 \\
(1.2 \%)\end{array}$ & $\begin{array}{c}175 \\
(2.8 \%)\end{array}$ & $\begin{array}{c}624 \\
(9.9 \%)\end{array}$ & $\begin{array}{c}1113 \\
(17.6 \%)\end{array}$ & $\begin{array}{c}1957 \\
(30.9 \% \\
\end{array}$ & $\begin{array}{c}2327 \\
(36.7 \%)\end{array}$ & 5.81 & 1.26 \\
\hline & $\begin{array}{l}\text { I am certain I can master the skills } \\
\text { that will be taught in this course. }\end{array}$ & $\begin{array}{c}65 \\
(1 \%)\end{array}$ & $\begin{array}{c}87 \\
(1.4 \%)\end{array}$ & $\begin{array}{l}190 \\
(3 \%)\end{array}$ & $\begin{array}{c}634 \\
(10 \%)\end{array}$ & $\begin{array}{c}1189 \\
(18.8 \%)\end{array}$ & $\begin{array}{c}1940 \\
(30.6 \% \\
\end{array}$ & $\begin{array}{c}2230 \\
(35.2 \%)\end{array}$ & $5 \cdot 77$ & 1.28 \\
\hline & $\begin{array}{l}\text { Considering the difficulty of this } \\
\text { course, the teacher, and my skills, I } \\
\text { think I will do well in this course. }\end{array}$ & $\begin{array}{c}60 \\
(0.9 \%)\end{array}$ & $\begin{array}{c}66 \\
(1 \%)\end{array}$ & $\begin{array}{c}157 \\
(2.5 \%)\end{array}$ & $\begin{array}{c}644 \\
(10.2 \%)\end{array}$ & $\begin{array}{c}1223 \\
(19.3 \%)\end{array}$ & $\begin{array}{c}2077 \\
(32.8 \% \\
)\end{array}$ & $\begin{array}{c}2108 \\
(33.3 \%)\end{array}$ & 5.77 & 1.23 \\
\hline
\end{tabular}

\section{Learning Strategies}

Learners assessed 12 MSLQ assertions about their usual learning strategies (Table 5), which gives hints about their strengths and weaknesses when facing MOOCs regarding organizational aspects. These assertions are grouped in two categories: CT (Critical Thinking), and TSE (Time and Study Environment). This second set of assertions was optional for those learners who completed the first 
set of assertions; each assertion of this second set received a maximum of 5956 answers and a minimum of 5875 answers.

The five assertions on CT obtained moderately high rates from learners, showing that they are able to question themselves about the concepts explained in the course $(M=5.08$, Std. $=1.50)$, look for supporting evidences $(M=5.20$, Std. $=1.39)$, and alternative explanations $(M=5.11$; Std. $=1.37)$. Learners also try to develop their own vision of what is explained in the course $(M=5.35$, Std. $=1.37)$, and connect the learned concepts with previous knowledge $(\mathrm{M}=5 \cdot 31, \mathrm{Std} .=1.38)$.

The two TSE assertions related to study environment received moderately high rates from learners, while the five TSE assertions related to time management show that there is margin of improvement. Regarding the study environment, it normally allows focusing in the course work $(\mathrm{M}=5.70$, Std. $=$ 1.37), although it is not always a dedicated study space $(M=4.72$, Std. 1.83). Regarding time management, learners consider they make a reasonable use of their study time ( $\mathrm{M}=4.93$, Std. $=1.46$ ), although present some difficulties to stick to the schedule $(M=4.31$; Std. $=1.79)$, have occasional distractions $(\mathrm{M}=4.19$, Std. = 1.72), and sometimes cannot find enough time to prepare for examinations $(M=3.58$, Std. $=1.78)$. Still, they are motivated to try to keep pace in the MOOC $(M=$ $5 \cdot 70$, Std. $=1.37)$.

Table 4

Learners'Self-Reported Answers to Assertions on Learning Strategies

\begin{tabular}{|c|c|c|c|c|c|c|c|c|c|c|c|}
\hline Type & Assertion & $\mathbf{1}$ & 2 & 3 & 4 & 5 & 6 & 7 & $\begin{array}{c}\text { Mea } \\
n\end{array}$ & Std. & $\mathbf{N} / \mathbf{A}$ \\
\hline \multirow{5}{*}{ CT } & $\begin{array}{l}\text { I often find myself } \\
\text { questioning things I } \\
\text { hear or read in course } \\
\text { that I am taking to } \\
\text { decide if I find them } \\
\text { convincing }\end{array}$ & $\begin{array}{c}145 \\
(2.5 \%)\end{array}$ & $\begin{array}{c}256 \\
(4.3 \%)\end{array}$ & $\begin{array}{c}450 \\
(7.6 \%)\end{array}$ & $\begin{array}{c}1024 \\
(17.3 \%)\end{array}$ & $\begin{array}{c}1415 \\
(23.9 \%)\end{array}$ & $\begin{array}{c}1534 \\
(25 \cdot 9 \%)\end{array}$ & $\begin{array}{c}1091 \\
(18.4 \%)\end{array}$ & 5.08 & 1.50 & 420 \\
\hline & $\begin{array}{l}\text { When a theory, } \\
\text { interpretation, or } \\
\text { conclusion is } \\
\text { presented in a course, } \\
\text { I try to decide if there } \\
\text { is good supporting } \\
\text { evidence. }\end{array}$ & $\begin{array}{c}81 \\
(1.4 \%)\end{array}$ & $\begin{array}{c}189 \\
(3.2 \%)\end{array}$ & $\begin{array}{c}405 \\
(6.8 \%)\end{array}$ & $\begin{array}{c}978 \\
(16.5 \%)\end{array}$ & $\begin{array}{c}1556 \\
(26.3 \%)\end{array}$ & $\begin{array}{c}1584 \\
(26.8 \%)\end{array}$ & $\begin{array}{c}1127 \\
(19 \%)\end{array}$ & 5.20 & 1.39 & 415 \\
\hline & $\begin{array}{l}\text { When I study, I treat } \\
\text { the course material as } \\
\text { a starting point and try } \\
\text { to develop my own } \\
\text { ideas about it. }\end{array}$ & $\begin{array}{c}64 \\
(1.1 \%)\end{array}$ & $\begin{array}{c}144 \\
(2.4 \%)\end{array}$ & $\begin{array}{c}387 \\
(6.5 \%)\end{array}$ & $\begin{array}{c}853 \\
(14.4 \%)\end{array}$ & $\begin{array}{c}1443 \\
(24.4 \%)\end{array}$ & $\begin{array}{c}1648 \\
(27.8 \%)\end{array}$ & $\begin{array}{c}1383 \\
(23.4 \%)\end{array}$ & $5 \cdot 35$ & 1.37 & 413 \\
\hline & $\begin{array}{l}\text { I try to play around } \\
\text { with ideas of my own } \\
\text { related to what I am } \\
\text { learning. }\end{array}$ & $\begin{array}{c}80 \\
(1.4 \%)\end{array}$ & $\begin{array}{c}142 \\
(2.4 \%)\end{array}$ & $\begin{array}{c}361 \\
(6.1 \%)\end{array}$ & $\begin{array}{c}936 \\
(15.9 \%)\end{array}$ & $\begin{array}{c}1475 \\
(25 \%)\end{array}$ & $\begin{array}{c}1568 \\
(26.6 \%)\end{array}$ & $\begin{array}{c}1336 \\
(22.7 \%)\end{array}$ & $5 \cdot 31$ & 1.38 & 437 \\
\hline & $\begin{array}{l}\text { Whenever I read or } \\
\text { hear an assertion or } \\
\text { conclusion in a course, } \\
\text { I think about possible } \\
\text { alternatives. }\end{array}$ & $\begin{array}{c}69 \\
(1.2 \%)\end{array}$ & $\begin{array}{c}186 \\
(3.2 \%)\end{array}$ & $\begin{array}{c}464 \\
(7.9 \%)\end{array}$ & $\begin{array}{c}1066 \\
(18.1 \%)\end{array}$ & $\begin{array}{c}1635 \\
(27.7 \%)\end{array}$ & $\begin{array}{c}1481 \\
(25.1 \%)\end{array}$ & $\begin{array}{c}991 \\
(16.8 \%)\end{array}$ & 5.11 & 1.37 & 443 \\
\hline \multirow{4}{*}{ TSE } & $\begin{array}{l}\text { I usually study in a } \\
\text { place where I can } \\
\text { concentrate on my } \\
\text { course work. }\end{array}$ & $\begin{array}{c}79 \\
(1.3 \%)\end{array}$ & $\begin{array}{c}115 \\
(1.9 \%)\end{array}$ & $\begin{array}{l}236 \\
(4 \%)\end{array}$ & $\begin{array}{c}597 \\
(10 \%)\end{array}$ & $\begin{array}{c}1224 \\
(20.6 \%)\end{array}$ & $\begin{array}{c}1501 \\
(25.2 \%)\end{array}$ & $\begin{array}{l}2204 \\
(37 \%)\end{array}$ & $5 \cdot 70$ & 1.37 & 379 \\
\hline & $\begin{array}{l}\text { I make good use of my } \\
\text { study time. }\end{array}$ & $\begin{array}{c}96 \\
(1.6 \%) \\
\end{array}$ & $\begin{array}{c}282 \\
(4.8 \%) \\
\end{array}$ & $\begin{array}{c}586 \\
(9.9 \%) \\
\end{array}$ & $\begin{array}{c}1178 \\
(19.9 \%) \\
\end{array}$ & $\begin{array}{c}1546 \\
(26.1 \%) \\
\end{array}$ & $\begin{array}{c}1312 \\
(22.2 \%) \\
\end{array}$ & $\begin{array}{c}920 \\
(15.5 \%) \\
\end{array}$ & 4.93 & 1.46 & 415 \\
\hline & $\begin{array}{l}\text { I find it hard to stick to } \\
\text { a study schedule }\end{array}$ & $\begin{array}{c}406 \\
(6.9 \%) \\
\end{array}$ & $\begin{array}{c}765 \\
(12.9 \%) \\
\end{array}$ & $\begin{array}{c}809 \\
(13.7 \%) \\
\end{array}$ & $\begin{array}{c}1055 \\
(17.8 \%) \\
\end{array}$ & $\begin{array}{c}1129 \\
(19.1 \%) \\
\end{array}$ & $\begin{array}{c}964 \\
(16.3 \%) \\
\end{array}$ & $\begin{array}{c}783 \\
(13.2 \%) \\
\end{array}$ & $4 \cdot 31$ & 1.79 & 424 \\
\hline & $\begin{array}{l}\text { I have a regular place } \\
\text { set aside for studying. }\end{array}$ & $\begin{array}{r}362 \\
(6.2 \%) \\
\end{array}$ & $\begin{array}{c}528 \\
(9 \%) \\
\end{array}$ & $\begin{array}{c}683 \\
(11.6 \%) \\
\end{array}$ & $\begin{array}{c}865 \\
(14.7 \%) \\
\end{array}$ & $\begin{array}{c}1039 \\
(17.7 \%) \\
\end{array}$ & $\begin{array}{c}1184 \\
(20.2 \%) \\
\end{array}$ & $\begin{array}{c}1214 \\
(20.7 \%) \\
\end{array}$ & $4 \cdot 72$ & 1.83 & 460 \\
\hline
\end{tabular}




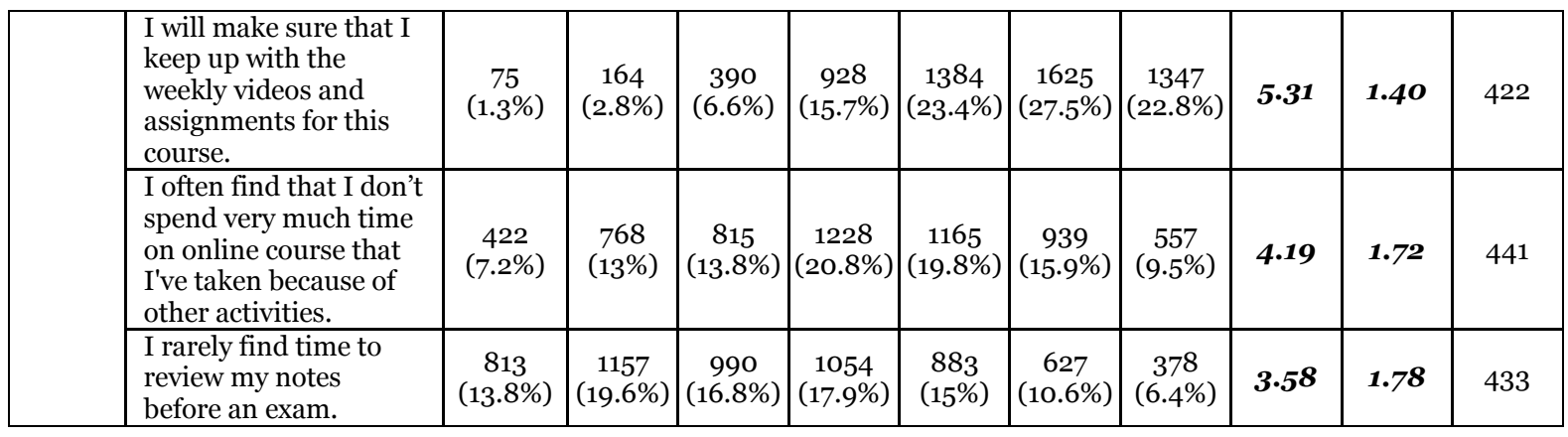

\section{Discussion}

This study provides a quantitative account to advance on the understanding of motivation and selfregulated learning strategies in MOOCs. Results are based on a large sample of 6335 MOOC learners with heterogeneous backgrounds and origins (160 countries). This analysis thus provides a broader scope with respect to the works by Morales Chan et al. (2015), and Kizilcec et al. (2017), in which an MSLQ-based questionnaire was applied to 230 learners enrolled in a MOOC on cloud-based tools for learning (in the first work), and to 4831 learners across six MOOCs in Spanish-speaking language (in the second work).

\section{Implications}

Results presented here allow us to answer the two research questions (RQ1 and RQ2) and have implications in understanding learners' motivation and learning strategies in MOOCs, and other similar learning environments. Concerning RQ1 ("What are the motivations that characterize MOOC learners?”), results on IGO show the changing trend in learners' preferences, going from being more interested in passing courses and getting certificates in residential education, to acquiring new knowledge through online learning (Rovai, Ponton, Wighting, \& Baker, 2007); this finding may partially explain the low completion rates in MOOCs. A lesson that can be learned is the need for designing MOOCs that are rich in exercises and assignments (even if these do not count for the final grade), so that learners can practice and better understand the contents of the course. In addition, results on TV partially explain the high figures of enrolled learners in the MOOC used in this study. It is noteworthy that MOOCs in the computer science field are among the most demanded ones (Ho et al., 2015), mainly because the obtained skills present a high demand in the current labor market (LinkedIn, 2016). A lesson that can be learned is the importance of offering courses in subjects and areas that awaken interest from learners, so that they at least come to the course with a high motivation level. Finally, results on SELP show a high level of confidence of learners, which can be partially explained by the lack of prerequisites for enrolment of this MOOC and by the fact $69.58 \%$ of learners already had some previous computing or statistical experience (see Table 2). A lesson that can be learned is the need for taking advantage of learners' initial high self-esteem level, and design MOOCs that, if tagged as introductory, really lack prerequisites. This can help to meet learners' expectations regarding the difficulty level of lectures, assignments, and exams.

Concerning RQ2 ("What are the self-regulated learning strategies that characterize MOOC learners?"), results on CT show a moderately high maturity of MOOC enrollees, who may be used to analyze, accept, and refute information from different sources in the Web, and to reach their own understanding and conclusions on the topics they want to learn. A lesson that can be learned is the need for equipping MOOC learners with the proper tools so that learners can build their own 
knowledge upon them. Fostering debate among the community of learners in the social tools around the MOOC seems to be also a good approach to confront different arguments and viewpoints. In addition, results on TSE show that not all the learners have properly developed the time management skills that are needed to keep pace in MOOCs. A lesson that can be learned is the need for providing balanced weekly contents so that learners can follow a routine, as well as clarifying from the very beginning the estimated weekly workload and the individual workload of each assignment

In order to advance on generalizing the answers to these two research questions, the results obtained in this work can be compared with those from similar studies. Comparing these results with those from the work by Morales Chan et al. (2015), whose supporting MOOC combines the computer science and education fields, it is possible to confirm that aggregated average scores are similar with respect to assertions on IGO. However, the study presented here has obtained slightly lower aggregated average scores in the cases of assertions related to TV and SELP, and slightly higher aggregated average scores in the cases of assertions related to CT and TSE. It is noteworthy that in the study by Morales Chan et al. (2015) the questionnaire was sent to learners in the second week of the MOOC and was available for only a week; therefore, all the learners already had an initial overview of the course materials and assignments, and their difficulty level before answering the questionnaire. In the study presented here, however, the questionnaire was included in an introductory week, although learners could complete the questionnaire at any time, as long as the course was still available. Learners following the course sequentially (which represent a significant number of learners) filled in the questionnaire before inspecting course materials and assignments. For completeness, it is important to point out that learners positively evaluated the materials of the MOOC in a survey conducted at the end of the course (Alario-Hoyos et al., 2016).

\section{Limitations}

This study has three main limitations that condition the generalization of the results and conclusions. The first limitation refers to external validity. This study is based on a MOOC on computer science, delivered in English, and where most of the learners are males, already have a Higher Education diploma, and some experience in computing or statistics. Still, this course combines learners enrolled in synchronous and self-paced modes, and from a wide range of countries (160). The latter advances on previous studies focused on a particular region, such as those by Morales Chan et al. (2015) or Kizilcec et al. (2017), which were focused on learners mainly from Spanish-speaking countries. This heterogeneity in learners' origins is of relevance, as social-cultural differences have an impact on learners' engagement in online courses (Guo \& Reinecke, 2014). The fact that the MOOC studied here is in the area of computer science can be indeed a factor that leads to an increase in the overall motivation of the learners, as this area has a great demand (Ho et al., 2015) due to the skills acquired promote employability (extrinsic motivation).

The second limitation refers to data reliability. The data obtained from this study could not be extracted directly from users' action in the MOOC. Instead we used a self-report questionnaire, which was completed by the learners themselves. Even though a large sample of learners filled in this questionnaire (6335), only $2.8 \%$ of those enrolled in the MOOC actually completed the questionnaire. Typically, the most motivated learners (intrinsic motivation) are the ones who take voluntary activities; this is reflected in the questionnaire with the answers to assertion "When I have the opportunity in this kind of courses, I try to do all the exercises and course assignments that I can learn from even if they don't guarantee a good grade" $(M=5.92$, Std. $=1.24)$. 
The third limitation refers to construct validity. The questionnaire used in this study contains a subset of MSLQ, which is a well-known and validated instrument (Pintrich et al., 1991; Pintrich, et al., 1993). MSLQ, although generally accepted, has been also criticized as it was designed in western homogeneous settings (Hamid \& Singaram, 2016). The questionnaire used in this study is focused on five categories (three regarding motivation, and two regarding learning strategies) that are relevant in the MOOC context. The selection of the subset of MSLQ is a trade-off between using a complete instrument with many items that do not fit in the educational context and creating an entirely new instrument ad hoc. In addition, asking volunteer learners to complete the entire MSLQ questionnaire demands a high workload, so there is also a trade-off regarding completeness and the number of responses that can be obtained in the study (Kizilcec et al., 2017).

\section{Conclusions and Future Work}

MOOCs typically consist of OER bundled following sequences of video-based lectures and assignments distributed in a weekly format. In MOOCs, learners' interaction occurs with OER, which are deployed in a MOOC platform, and with other learners, through the course forum and other social tools. The global impact of MOOCs brings together learners with many different profiles and motivations. In addition, the format of these courses, without supervised tutoring, demands new selflearning skills on learners. In order to shed some light on the motivations and learning strategies of MOOC learners, this paper conducted an empirical analysis with 6335 learners from a MOOC titled Introduction to Programming with Java. The empirical study is supported by the MSLQ Likert-type questionnaire. Self-reported answers from learners about their motivation show high values on Intrinsic Goal Orientation and Self-Efficacy for Learning and Performance, and very high values on Task Value. Self-reported answers from learners about their learning strategies show moderately high values on Critical Thinking Skills and Time and Study Environment, although time management is an aspect that learners need to improve. MOOCs shall therefore be designed to facilitate time management to learners. Early precise estimations of the weekly workload and of the individual workload of each assignment, detailed specifications of mandatory and optional tasks, and analyses of average times devoted by learners based on their previous backgrounds, can help to better manage time among MOOC learners.

Future lines of work must address the three main limitations of this study. First, regarding external validity, similar analyses with large populations of MOOC learners shall be conducted in other areas, particularly in natural sciences and social sciences. Moreover, learners' motivation may be very different when taking MOOCs aimed at promoting professional development as compared to MOOCs aimed at satisfying curiosities or improving general culture. Likewise, similar analyses on learners' motivation and learning strategies can be conducted in advanced courses, as the MOOC used in this study was an introductory course. Advanced courses typically have prerequisites, which entail a first filtering for enrollees. In some cases, advanced courses are part of sequences of related MOOCs, and so, enrollees may have previous experiences with similar MOOCs, which may affect both their perception of their motivation and learning strategy. The way the course is designed can also lead to interesting results; for example, Cohen and Magen-Nagar (2016) suggest that project-based learning subjects have a significant positive impact on motivational orientations and learning strategies. Second, regarding data reliability, future work shall analyze the relationship between learners' answers to the questionnaire and their actual performance in the course, including variables such as 
grades in the different assignments, and whether the learners completed the MOOC or not. This analysis was not carried out in this study because the questionnaire filled in by learners was anonymous and the answers could not be matched with learners' performance throughout the course. And third, regarding construct validity, deeper analysis can be done combining other instruments from the literature, such as those by Barnard et al. (2008) or Jansen et al. (2016), to gain further insights on learners' motivation and self-regulated learning strategies.

\section{Acknowledgements}

This work has been co-funded by the Erasmus+ Programme of the European Union, projects MOOCMaker (561533-EPP-1-2015-1-ES-EPPKA2-CBHE-JP), SHEILA (562080-EPP-1-2015-BE-EPPKA3PI-FORWARD) and COMPETEN-SEA (574212-EPP-1-2016-1- NL-EPPKA2-CBHE-JP), by the Madrid Regional Government, through the eMadrid Excellence Network (S2013/ICE-2715), and by the Spanish Ministry of Economy and Competitiveness, project RESET (TIN2014-53199-C3-1-R) and fellowships FPDI-2013-17411 and PTQ-15-07505.

\section{References}

Abelson, H. (2008). The creation of OpenCourseWare at MIT. Journal of Science Education and Technology, 17(2), 164-174.

Alario-Hoyos, C., Pérez-Sanagustín, M., Delgado Kloos, C., Parada G., H. A., Muñoz-Organero, M., \& Rodríguez-de-las-Heras, A. (2013). Analysing the impact of built-in and external social tools in a MOOC on educational technologies. In Proceedings of the European Conference on Technology Enhanced Learning, EC-TEL 2013, (pp. 5-18). Springer Berlin Heidelberg.

Alario-Hoyos, C., Delgado Kloos, C., Estévez-Ayres, I., Fernández-Panadero, C., Blasco, J., Pastrana, S., ... Villena-Román, J. (2016). Interactive activities: the key to learning programming with MOOCs. In Proceedings of the Fourth European MOOCs Stakeholders Summit, EMOOCs 2016, (pp. 319-328).

Atkins, D. E., Brown, J. S., \& Hammond, A. L. (2007). A review of the open educational resources (OER) movement: Achievements, challenges, and new opportunities. William and Flora Hewlett Foundation. Retrieved from http://www.hewlett.org/wpcontent/uploads/2016/08/ReviewoftheOERMovement.pdf

Bannert, M., \& Reimann, P. (2012). Supporting self-regulated hypermedia learning through prompts. Instructional Science, 4O(1), 193-211.

Barnard, L., Paton, V., \& Lan, W. (2008). Online self-regulatory learning behaviors as a mediator in the relationship between online course perceptions with achievement. The International Review of Research in Open and Distributed Learning, 9(2). 
Carson, S., Kanchanaraksa, S., Gooding, I., Mulder, F., \& Schuwer, R. (2012). Impact of OpenCourseWare publication on higher education participation and student recruitment. The International Review Of Research In Open And Distributed Learning, 13(4), 19-32.

Collazos, C. A., González, C. S., \& García, R. (2014). Computer supported collaborative MOOCs: CSCM. In Proceedings of the 2014 Workshop on Interaction Design in Educational Environments (p. 28). ACM.

Clow, D. (2013). MOOCs and the funnel of participation. In Proceedings of the Third International Conference on Learning Analytics and Knowledge, (pp. 185-189). ACM.

Cohen, L., \& Magen-Nagar, N. (2016). Self-Regulated Learning and a sense of achievement in MOOCs among high school science and technology students. American Journal of Distance Education, 3o(2), 68-79.

Colorado, J. T., \& Eberle, J. (2010). Student demographics and success in online learning environments. Emporia State Research Studies, 46(1), 4-10.

Davis, H. C., Dickens, K., Leon Urrutia, M., Sánchez-Vera, M. M., \& White, S. (2014). MOOCs for Universities and learners an analysis of motivating factors. University of Southampton. Retrieved from http://eprints.soton.ac.uk/363714/

De Barba, P. G., Kennedy, G. E., \& Ainley, M. D. (2016). The role of students' motivation and participation in predicting performance in a MOOC. Journal of Computer Assisted Learning, 32(3), 218-231.

DeBoer, J., Stump, G. S., Seaton, D., Ho, A., Pritchard, D. E., \& Breslow, L. (2013). Bringing student backgrounds online: MOOC user demographics, site usage, and online learning. In Proceedings of Educational Data Mining 2013 (pp. 312-313).

Deci, E. L., Vallerand, R. J., Pelletier, L. G., \& Ryan, R. M. (1991). Motivation and education: The selfdetermination perspective. Educational Psychologist, 26(3-4), 325-346.

Fontana, R. P., Milligan, C., Littlejohn, A., \& Margaryan, A. (2015). Measuring self-regulated learning in the workplace. International Journal of Training and Development, 19(1), 32-52.

Fox, A. (2013). From MOOCs to SPOCs. Communications of the ACM, 56(12), 38-40.

Gasevic, D., Kovanovic, V., Joksimovic, S., \& Siemens, G. (2014). Where is research on massive open online courses headed? A data analysis of the MOOC Research Initiative. The International Review of Research in Open and Distributed Learning, 15(5), 134-176.

Gené, O. B., Núñez, M. M., \& Blanco, Á. F. (2014). Gamification in MOOC: Challenges, opportunities and proposals for advancing MOOC model. In Proceedings of the Second International Conference on Technological Ecosystems for Enhancing Multiculturality (pp. 215-220). ACM.

Gottfried, A. E., Marcoulides, G. A., Gottfried, A. W., Oliver, P. H., \& Guerin, G. W. (2007). Multivariate latent change modeling of developmental decline in academic intrinsic math 
motivation and achievement: Childhood through adolescence. International Journal of Behavioral Development, 31, 317-327.

Guo, P. J., \& Reinecke, K. (2014). Demographic differences in how students navigate through MOOCs. In Proceedings of the first ACM conference on Learning@ scale conference (pp. 21-30). ACM.

Gutiérrez-Rojas, I., Alario-Hoyos, C., Pérez-Sanagustín, M., Leony, D., \& Delgado Kloos, C. (2014). Scaffolding self-learning in MOOCs. In Proceedings of the Second MOOC European Stakeholders Summit, EMOOCs 2014, (pp. 43-49).

Halawa, S., Greene, D., \& Mitchell, J. (2014). Dropout prediction in MOOCs using learner activity features. eLearning Papers, 37, 7-16.

Hamid, S., \& Singaram, V. S. (2016). Motivated strategies for learning and their association with academic performance of a diverse group of 1st-year medical students. African Journal of Health Professions Education, 8(1), 104-107.

Ho, A. D., Reich, J., Nesterko, S., Seaton, D. T., Mullaney, T., Waldo, J., \& Chuang, I. (2014). HarvardX and MITx: The first year of open online courses (HarvardX and MITx Working Paper No. 1). Harvard and MIT. Retrieved from http://ssrn.com/abstract=2381263

Ho, A. D., Chuang, I., Reich, J., Coleman, C., Whitehill, J., Northcutt, C., ... Petersen, R. (2015). HarvardX and MITx: Two years of open online courses (HarvardX Working Paper No. 10). Harvard and MIT. Retrieved from http://ssrn.com/abstract=2586847

Hood, N., Littlejohn, A., \& Milligan, C. (2015). Context counts: How learners' contexts influence learning in a MOOC. Computers \& Education, 91, 83-91.

Jansen, R. S., Van Leeuwen, A., Janssen, J., Kester, L., \& Kalz, M. (2016). Validation of the selfregulated online learning questionnaire. Journal of Computing in Higher Education, 1-22.

Kizilcec, R. F., \& Halawa, S. (2015). Attrition and achievement gaps in online learning. In Proceedings of the Second ACM Conference on Learning@Scale, (pp. 57-66). ACM.

Kizilcec, R. F., Pérez-Sanagustín, M., \& Maldonado, J. J. (2016). Recommending self-regulated learning strategies does not improve performance in a MOOC. In Proceedings of the Third ACM Conference on Learning@ Scale (pp. 101-104). ACM.

Kizilcec, R. F., Pérez-Sanagustín, M., \& Maldonado, J. J. (2017). Self-regulated learning strategies predict learner behavior and goal attainment in Massive Open Online Courses. Computers \& Education, 104, 18-33.

Lee, M. K., Cheung, C. M., \& Chen, Z. (2005). Acceptance of Internet-based learning medium: The role of extrinsic and intrinsic motivation. Information \& management, 42(8), 1095-1104.

LinkedIn. (2016). The 25 skills that can get you hired in 2016 [Web blog post], Retrieved from http://www.slideshare.net/linkedin/the-25-skills-that-could-get-you-hired-in-2016 
Lin, X., Hmelo, C., Kinzer, C. K., \& Secules, T. J. (1999). Designing technology to support reflection. Educational Technology Research and Development, 47(3), 43-62.

Littlejohn, A., \& Milligan, C. (2016). Designing MOOCs for professional learners: Tools and patterns to encourage self-regulated learning. The Internet and Higher Education, 29, 40-48.

Liyanagunawardena, T. R., Adams, A. A., \& Williams, S. A. (2013). MOOCs: A systematic study of the published literature 2008-2012. The International Review of Research in Open and Distributed Learning, 14(3), 202-227.

Magen-Nagar, N., \& Cohen, L. (2016). Learning strategies as a mediator for motivation and a sense of achievement among students who study in MOOCs. Education and Information Technologies, 2016, 1-20.

Morales Chan, M., Hernández Rizzardini, R., Barchino Plata, R., \& Amelio Medina, J. (2015). MOOC using cloud-based tools: A study of motivation and learning strategies in Latin America. International Journal of Engineering Education, 31(3), 901-911.

Nawrot, I., \& Doucet, A. (2014). Building engagement for MOOC students: Introducing support for time management on online learning platforms. In Proceedings of the 23rd International Conference on World Wide Web (pp. 1077-1082). ACM.

Pappano, L. (2012). The year of the MOOC. The New York Times. Retrieved from http://www.nytimes.com/2012/11/o4/education/edlife/massive-open-online-courses-aremultiplying-at-a-rapid-pace.html

Pintrich, P. R. (1999). The role of motivation in promoting and sustaining self-regulated learning. International journal of educational research, 31(6), 459-470.

Pintrich, P. R., Smith, D. A., García, T., \& McKeachie, W. J. (1991). A manual for the use of the Motivated Strategies for Learning Questionnaire (MSLQ), National Center for Research to Improve Postsecondary Teaching and Learning. University of Michigan. Retrieved from https://eric.ed.gov/?id=ED338122

Pintrich, P. R., Smith, D. A., García, T., \& McKeachie, W. J. (1993). Reliability and predictive validity of the Motivated Strategies for Learning Questionnaire (MSLQ). Educational and Psychological Measurement, 53(3), 801-813.

Puustinen, M., \& Pulkkinen, L. (2001). Models of self-regulated learning: A review. Scandinavian Journal of Educational Research, 45(3), 269-286.

Riel, J., \& Lawless, K. A. (2017). Developments in MOOC technologies and participation since 2012: Changes since "The year of the MOOC." In M. Khosrow-Pour (Ed.), Encyclopedia of information science and technology (4th Ed.), Hershey, PA: IGI Global.

Rovai, A. P., Ponton, M. K., Wighting, M. J., \& Baker, J. D. (2007). A comparative analysis of student motivation in traditional classroom and e-learning courses. International Journal on ELearning, 6(3), 413-432. 
Ryan, R. M., \& Deci, E. L. (2000). Self-determination theory and the facilitation of intrinsic motivation, social development, and well-being. American Psychologist, 55(1), 68-78.

Schunk, D. H., \& Zimmerman, B. J. (Eds.). (1998). Self-regulated learning: From teaching to selfreflective practice. New York, NY: Guilford Press.

Schunk, D. H. (2005). Self-regulated learning: The educational legacy of Paul R. Pintrich. Educational Psychologist, 4O(2), 85-94.

Terras, M. M., \& Ramsay, J. (2015). Massive open online courses (MOOCs): Insights and challenges from a psychological perspective. British Journal of Educational Technology, 46(3), 472-487.

Vaibhav, A., \& Gupta, P. (2014). Gamification of MOOCs for increasing user engagement. In 2014 IEEE International Conference on MOOC, Innovation and Technology in Education (MITE) (pp. 290-295). IEEE.

Veletsianos, G., \& Shepherdson, P. (2016). A systematic analysis and synthesis of the empirical MOOC literature published in 2013-2015. The International Review of Research in Open and Distributed Learning, 17(2), 198-221.

Wang, Y., \& Baker, R. (2015). Content or platform: Why do students complete MOOCs? Journal of Online Learning and Teaching, 11(1), 17.

Yuan, L., \& Powell, S. (2013). MOOCs and open education: Implications for higher education. JISC CETIS. Retrieved from http://publications.cetis.org.uk/2013/667

Zheng, S., Rosson, M. B., Shih, P. C., \& Carroll, J. M. (2015). Understanding student motivation, behaviors and perceptions in MOOCs. In Proceedings of the 18th ACM Conference on Computer Supported Cooperative Work \& Social Computing (pp. 1882-1895). ACM.

Zimmerman, B. J. (2002). Becoming a self-regulated learner: An overview. Theory into practice, 41(2), 64-70.

\section{Athabasca}

University

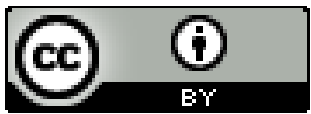

